\title{
1. Introduction: evaluating the relationship between economic policy and manufacturing sector performance
}

\section{Oliver Morrissey and Michael Tribe}

\section{INTRODUCTION}

One of the principal issues associated with the analysis of the relationship between economic policy and manufacturing sector performance lies in the definition of 'economic policy'. The term 'economic policy reform' has, in recent years, been linked in the literature principally with macroeconomic stabilisation, trade and exchange rate liberalisation, financial market liberalisation, and the removal of a wide range of controls and distortions that had become entrenched in many developing and transitional economies. However, 'economic policy' is a broader concept than this. Many countries have attempted to introduce policy instruments which extend beyond the conventional view of macroeconomic policy, especially, from our perspective, into areas of industrial policy (one could also include labour policy).

The essays in this volume do not attempt to employ a uniform definition of economic policy. Rather, they take as their focus an aspect of the performance of the manufacturing sector, and attempt to assess how and which economic policies have affected performance. From this perspective, some lessons for economic policy towards manufacturing can be drawn. The geographical range of the studies is intentionally wide. Although the majority of chapters relate to countries in sub-Saharan Africa (SSA), we include cases in South and East Asia, South America and the Middle East (thereby extending the study of Jalilian et al., 2000). Furthermore, the chapters focus on various aspects of manufacturing - small enterprises, technology, the exporting sector and manufacturing in general. In this introduction we attempt to highlight some of the common themes and lessons that emerge.

Trade policy reform has been one of the most prevalent areas of economic policy reform in developing countries over the past decade or so, with direct implications for manufacturing. While Jalilian et al. (2000) addressed this primarily from the perspective of the impact on import-competing sectors, 
here the focus is more often on exporting. One of the aims of trade liberalisation is to stimulate export performance and encourage diversification. There is now considerable evidence to support the view that trade liberalisation contributes to export growth and diversification primarily through the removal of a bias against exports (see Section 2 below). Most of the evidence of successful liberalisation relates to high- and middle-income developing countries. The experience of low-income developing countries, which lack efficient physical infrastructure and rely extensively on the production of primary products, is less encouraging. This is particularly true in respect of manufacturing. A study of experiences in sub-Saharan Africa (SSA) suggests that while export diversification is slow to materialise, trade liberalisation is generally beneficial for the economy because it stimulates exports and efficiency gains due to reduced protection (Morrissey, 1999). However, lowincome developing countries share characteristics that constrain export growth and limit the effectiveness of trade policy reforms. The analysis of the experience of a large number of developing countries from different backgrounds would provide a better insight into the response of liberalisation in different economic environments and enable the formulation of more appropriate policy measures, tailored to the specific needs of those countries. The aim of this volume is to provide such an analysis.

\section{ECONOMIC POLICY REFORM AND TRADE LIBERALISATION}

Motivated primarily by the World Bank under its policy of structural adjustment since the early 1980s, virtually all developing countries have engaged in economic policy reform, liberalisation in virtually all cases, over the past two decades. Trade liberalisation, the removal of restrictions on imports and reduction of discrimination against exports, has been the single most important area of policy reform in almost all cases (Greenaway and Morrissey, 1994). Liberalisation of exchange rate regimes, of agricultural policy (especially removal of price controls and state monopolies in marketing) and improved investment incentives have also been prevalent (Greenaway and Morrissey, 1993). All of these reforms have potential implications for manufacturing and these are discussed in this section. Policy reforms with a direct effect on manufacturing, such as privatisation and investment promotion, are of more recent vintage and are discussed in the next section.

The outcomes of the many liberalisation episodes have been mixed (see McGillivray and Morrissey, 1999; Papageorgiou et al., 1991). There is evidence that liberalisation is associated with economic growth, though not necessarily in manufacturing. Onafowora and Owoye (1998) find evidence 
that growth is higher in more outward-oriented African economies as compared with more protective economies, and infer that trade liberalisation (which increases outward orientation) offers potential for low-income countries to increase growth rates. They recognise that the commodity composition of exports, especially dependence on a narrow range of primary products, can constrain the contribution of exports to growth. While the balance of the evidence suggests that outward orientation is associated with better growth, the link between trade liberalisation per se and better growth performance is rather weak (Greenaway et al., 1997, 1998). Often this is because the anticipated export supply response fails to materialise following liberalisation. The econometric evidence should be interpreted very carefully as cross-country studies are limited to using simple measures of liberalisation (such as a dummy variable for when a reform episode occurred, or changes in average nominal tariffs). These simple measures are likely to be both inaccurate and misleading (Milner and Morrissey, 1999).

It is helpful to distinguish separate elements of trade liberalisation. Import liberalisation - the removal of quantitative restrictions (QRs) and the reduction of tariffs - reduces the price of imports and importables (domestically produced goods that compete with imports). This reduction of protection is expected to benefit the economy by reducing the inefficiencies in resource allocation typically associated with protectionist, import substituting (IS) policies. An important effect of reducing protection is that it reduces the bias against exports, although this alone may be insufficient to encourage investors to reallocate resources from the production of importables to production of exportables. Export promotion measures can directly facilitate and increase the return to exporting. Allowing exporters to retain export earnings is a simple (and potentially effective) export promotion measure. Devaluation of the exchange rate can also increase returns to exporters (as they receive more domestic currency for a given world price) and generally has the effect of increasing the price of exportables relative to importables (i.e. reducing the anti-export bias). There is evidence that the real exchange rate is the most important determinant of export growth (Noorbakhsh and Paloni, 1998).

Doubts that trade liberalisation may benefit developing countries remain strong (Rodrik, 1999). The removal of tariff subsidies and QRs exposes domestic firms (that may have become inefficient because of protection) to increased competition from imports. Consequently, trade liberalisation can have undesirable side effects in the short run. Greenaway (1998) argues that these will depend on initial conditions and the sequencing of reforms. The short to medium term responses to trade reforms are on the allocation of factors (especially labour but also investment) and the composition of output, as resources switch from inefficient import substitution to exporting. The medium to long term impact of trade reforms should be reflected in capital 
formation and growth of real output and trade. Often the adverse adjustment costs, as some firms close for example, are observed more immediately than the positive benefits. For example, for a variety of reasons, it can take some time before exports can actually be increased. As the impact of any policy reform takes time, and as typically a variety of reforms with often conflicting effects are implemented during a period, it is exceedingly difficult to identify the effects of specific reforms - see McGillivray and Morrissey (1999) for elaboration on this.

\section{POLICY REFORM AND MANUFACTURING PERFORMANCE}

Most studies of the impact of policy reform on manufacturing have studied performance during a period of trade liberalisation. Bennell (1998) finds that liberalisation does not appear to have had an adverse effect on the manufacturing sector in SSA countries in general, although some countries experienced a decline in output. Grenier et al. (1999) note that the manufacturing sector in Tanzania increased output during the period of trade liberalisation. Evidence from Nepalese manufacturing indicates some growth in manufacturing output following trade liberalisation; however, there was no significant productivity growth, although the rate of decline in productivity growth was reduced (Sharma et al. 2000). Acheampong and Tribe (this volume, Chapter 2) find similar results for Nepal and Ghana. Put simply, the evidence is mixed albeit generally favourable to some degree of liberalisation.

Mulaga and Weiss (1996) analyse the Malawian manufacturing sector over the period 1970 to 1991 , using firm-level data. This was a period of substantial changes in trade policy. When the entire period is separated into relatively 'open' and 'closed' sub-periods, it is clear that productivity and value added tended to grow more when the economy was open. Of course, trade policy is only one factor affecting productivity, so that without careful analysis of other policy areas (and of other influences on manufacturing performance) it would not be possible to come to a strong conclusion (Rodrik, 1992b: 102). This caveat applies to all countries.

Helleiner (1994: 8-32) notes that when industrial output is decomposed using the Chenery methodology (Chenery et al., 1986) into its demand-side constituents, most industrial growth during adjustment follows from growth in domestic demand. By comparison, studies of Ghana (this volume, Chapter 2) and Malawi (Mulaga and Weiss, 1996) suggest that much of the industrial recovery should be attributed to improved capacity utilisation, due to easier availability of inputs, and place the emphasis on the supply side rather than the demand side. For SSA countries, it should also be noted that the manufac- 
turing industries that recovered were principally developed in an earlier import substitution period, suggesting that import substitution industrialisation has had a sustainable impact on the economy. This should be set against the rather negative view of import substitution that tends to appear in the literature. The recovery would not have been possible if the industries had not already been in place, so that long-term industrialisation can be based at least in part on an initial phase of import substitution.

The dichotomy between import substitution and export promotion is often overemphasised (Lall and Wangwe, 1998: 75 and 79). The experiences of Japan, South Korea and the other successful East Asian countries show that import substitution played a major role in the early stages of development (Rodrik, 1992a: 310). Chhibber and Leechor (1995) consider the extent to which the lessons from the East Asian experience can be applied to SSA countries. They emphasise the 'usual suspects' - human capital, financial institutions, public sector and economic management, institutional development, and the nature of political and economic risk - but suggest caution in interpreting the relationship between policy and manufacturing growth and efficiency. A number of factors other than the trade policy environment emerge in many studies as important determinants of the performance of manufactured exports:

a. Scale - Firms considered too large during the import substitution phase seem to be too small to be competitive (in foreign markets) in an exportoriented phase. In general, certainly for SSA countries, exporting firms are far more likely to be large firms and large firms are more likely to export (Grenier et al., 2000; Söderbom and Teal, 2000). Middleton (this volume, Chapter 9) and Thoburn (this volume, Chapter 5) both emphasise the suitability of microenterprises for providing the goods demanded domestically by low-income consumers.

b. Finance - Access to long-term finance, rationed credit and high interest rates are all identified as major constraints. There is some evidence for this in Ghana (Acheampong and Tribe, this volume, Chapter 2) and Gaza (Migdad et al., this volume, Chapter 10). Grenier et al. (2000) report similar evidence for Tanzanian firms. Livingstone (this volume, Chapter 8) discusses the problems facing small enterprises in Cambodia in gaining access to adequate credit; they also face rationing and high interest rates. Access to finance is a major determinant of investment, itself a principal determinant of manufacturing performance (Arun and Nixson, this volume, Chapter 7).

c. Raw material costs and availability create problems for exporting firms as well as for those supplying the domestic market (Migdad et al., this volume, Chapter 10). This is especially a problem when tariffs increase 
the costs of imported inputs; Thoburn (this volume, Chapter 5) notes that delays and difficulties in getting refunds on tariffs and VAT paid on inputs places exporters at a competitive disadvantage.

d. Technology - Technological obsolescence and poor equipment are major impediments to many firms, especially exporters, who blame these for low productivity and the difficulty in achieving product quality for export markets (Acheampong and Tribe, this volume, Chapter 2; Mainga, this volume, Chapter 3). This emphasis on the shortcomings of technical efficiency and technological progress as a major constraint on industrial development in sub-Saharan Africa is also emphasised by the African Development Bank (1998: 60).

e. Infrastructure - many firms complain about the prices and unreliability of electricity and water supply. Livingstone (this volume, Chapter 8), in the case of microenterprises in Cambodia, and Milner et al. (2000) in respect of manufacturing in Uganda, note the major impediment to trade associated with high transport costs (largely due to a low quality of transport infrastructure). Livingstone (this volume, Chapter 8) also notes that microenterprises cite the high cost of power supply as a problem.

Lall and Wangwe (1998) provide an overview of the nature of and experience with industrial policy in SSA, distinguishing between trade policy on the one hand and specific policy relating to the industrial sector on the other. Although this distinction is important in clarifying the types of actions considered to be 'policy reform', it is not always drawn clearly. In considering broad macroeconomic policies relating to - for example - international trade and payments, it is very difficult in practice to identify which particular economic gains or losses are attributable to which particular aspects of policy change. For this reason, the contributions to this volume refer to 'policy' in a general sense, because economy-wide and industry-specific policy changes tend to be implemented together and their impacts are difficult to separate. Nevertheless, in some countries trade and macroeconomic reforms preceded, often by many years, specific measures aimed at industry. Where appropriate, the contributions try to isolate specific from general policy impacts. Another problem, of course, is that it is difficult to identify when policies have an impact - the significance of time lags is often underestimated (Acheampong and Tribe, 1998; Arun and Nixson, this volume, Chapter 7).

A particular concern of analysts of manufacturing in SSA is the potentially damaging effects of liberalisation:

Liberalisation has led large swathes of the manufacturing sector to be devastated by import competition. Industrial survivors and new entrants are basically in activities that have 'natural' protection from imports: very small-scale enterprises, 
making low-income or localised products, and larger enterprises protected by high transport costs or based on processing of local raw materials. (Lall and Wangwe, 1998: 81)

However, there appears to be no consensus about the precise definition of the phenomenon of 'de-industrialisation' let alone over the extent to which empirical verification should be undertaken. Several chapters in a recent book focused on sub-Saharan Africa address themselves to the 'de-industrialisation' issue (Jalilian et al. 2000). In addition to the above, others have also elucidated the a priori expectation that liberalisation (and structural adjustment in general) might lead to a decline in manufacturing production in African countries. This may be due to increased competition for formerly protected domestic industries from imports, and/or to the lack of global competitiveness provided by African industries in terms of manufactured export development - see in particular Bennell (1998). However, experience is mixed, with some countries (for example Ghana and Uganda) exhibiting strong recovery from economic decline (not least in manufacturing production) following structural adjustment and liberalisation programmes, and SSA generally experiencing sustained manufacturing growth during the 1980s and into the 1990s (Tribe, 2000).

This issue, and a number of other issues thrown up in the course of the Jalilian et al. (2000) volume were suggestive that a broader global view of the nature and impact of policy towards the development of the manufacturing sector in developing countries would be of interest. The chapters in this volume should therefore be viewed in this context. It is indisputable that the 1980s and 1990s have witnessed a sea change in attitudes to the role of government policy towards what has become predominantly private sector manufacturing sector development.

\section{OVERVIEW OF THE VOLUME}

Acheampong and Tribe (Chapter 2) note that generalisation about the level of, and changes in, manufacturing efficiency cannot easily be justified - some countries have performed worse than others, and some countries show signs of improvement while others have deteriorated. Subject to this caveat, calculations of total factor productivity growth (TFPG), a standard tool of analysis, is instructive; at the least, TFPG for countries in which manufacturing has performed poorly is not very encouraging. Many factors affect productivity growth at the enterprise level. Some relate to entrepreneurial or managerial actions of the firm - management restructuring, retraining of labour, reorganisation of labour to undertake new tasks. Others relate to investment and 
technology - increasing capital per employee, installation of new equipment or rehabilitation of machinery. These too are policies or actions of the firm. Government policies alter the environment - increasing availability of foreign exchange, increasing availability of inputs, growth in the level of demand and improved infrastructure. Improving the 'government policy environment' is a specific aim of adjustment or liberalisation.

Recent work on Ghanaian manufacturing has been based on a period which largely follows that covered in Acheampong and Tribe (Chapter 2), and is based on firm-level panel data rather than on sector-wide data from the Ghana Statistical Service. Teal (1998) finds that, over the period 1991-95, real value added for the sector grew by 17 per cent, or about 4 per cent per annum, but that over the five year period there was no evidence of a growth in underlying productivity. This conclusion is broadly consistent with the findings of Acheampong and Tribe (Chapter 2), whereby output growth has largely been achieved by increased capacity utilisation, with any changes in TFPG likely to have been negative - or at least very low - in the early 1990s. It appears to be the case, at least in Ghana, that "substantial firm growth has occurred by increasing both labour and capital inputs with zero technical progress' (Teal, 1998: 9).

A common source of export growth is a widening of the market, which can be induced by a significant depreciation of the domestic currency relative to competitors. If accompanied by policy reform this can encourage firms both to increase exports and to increase production for the domestic market. Acheampong and Tribe (Chapter 2) suggest that this occurred in Ghana, and some firms reinforced this (i.e. responded to incentives) by improving product quality, adopting new production processes and diversifying product lines. Of course external events can cause the market to contract, and exports will decline for reasons outside the control of the country; Thoburn (Chapter 5) provides an illustration in the case of Indonesia. Nevertheless, appropriate domestic policies can strengthen the competitiveness of exporters, and may enable them to, at least partially, 'buck' global trends. Rudaheranwa (Chapter 4) shows that, for Uganda, domestic supply-side factors were more important in export growth than demand factors (growth in export markets).

Mainga (Chapter 3) emphasises the importance of developing firm-level capability building, particularly in the area of technological capabilities, as a basis for significant positive response to the opportunities presented by national-level economic adjustment programmes. Using Zambian firm-level survey data collected in the course of his doctoral research, Mainga assesses the extent to which specific capabilities have been demonstrated by firms, and the characteristics that have some explanatory power over responsive and adaptive behaviour. He emphasises that getting prices right is only part of the story; learning mechanisms determine the ability of firms to develop specific 
capabilities. This conclusion is consistent with the emphasis given by Chhibber and Leechor (1995) to the significance of managerial capability for responsive manufacturing development - a lesson from the Asian 'tiger' economies that had not been given prominence previously. Mainga's arguments are intuitively appealing, and his detailed discussion of forms and processes of 'technological learning', distinguishing between knowledge about i) productive technology, ii) work practices and the organisation of production, iii) customers, suppliers and complementary institutions, and iv) the evolution of target markets, is very illuminating. He also distinguishes between four different types of technology, relating to production, information, human capital and institutions. Essentially, the implication of Mainga's argument is that the capacity for manufacturing firms to respond effectively to policy shifts depends to a considerable extent on their technological and managerial capability. Liberalisation and adjustment would therefore be regarded as necessary, but not sufficient, conditions for the achievement of improvements in manufacturing sector competitiveness. The same line of argument would apply to the capacity for firm-level responsiveness to any other policy shift - for example in the area of environmental protection.

Rudaheranwa (Chapter 4) conducts a 'constant market share' analysis of the changing competitiveness of Ugandan exporters. It is clear that export performance is very sensitive to competitiveness; that is, just less than twothirds of export growth is due to the competitive factor. It is also evident that supply conditions had the greater impact on Ugandan export growth (over 64 per cent) whereas demand conditions (in export markets) accounted for less than 20 per cent of growth. Most of the growth in Ugandan exports was in agricultural commodities, especially traditional exports such as coffee, which is to be expected given the structure of the economy. Nevertheless, there was significant growth in some manufacturing, mostly chemicals and textiles, to African and European countries. There is no evidence that manufacturing output overall declined during the 1990s (Rudaheranwa, 1999), and some evidence that manufacturing exports increased following liberalisation. More importantly, the results suggest that the limited improvement in Ugandan export performance, including manufactures, was largely attributable to Ugandan reforms (supply side conditions). This is evidence for a potentially beneficial effect of liberalisation, even if export response is slow. It is clear that Uganda will find it difficult to increase the volume and diversity (composition and destination) of exports without adopting a strategy that reduces costs arising from inefficient transport and associated infrastructure facilities.

Thoburn (Chapter 5) addresses the slow down in Indonesian export growth in the early 1990s. The main role of the government in support of exporters was in providing export companies with a more competitive domestic economic environment that is attractive to foreign investors. It is important that 
exporters have access to traded inputs at world prices, and face an undistorted choice between purchasing inputs locally or through imports. They also require a competitive exchange rate. Indonesia achieved much of this until the mid-1990s. Indonesia's export promoting trade regime was supported by export processing zones (EPZs) and institutions to refund taxes on inputs (tariffs and VAT), Bapeksta and the EPTE facility (which competed with each other in an institutional sense). The fact that Bapeksta became less effective in providing tax refunds, and devoted more attention to auditing against fraud, was one reason for the slowdown in exports, especially of textiles and garments, in the mid-1990s. What this study highlights is that effective export promoting measures are those that alleviate the adverse effects of policy barriers to trade - protection of imports tends to disprotect exports. An important question is whether the restoration of undistorted input and export prices (by providing tax refunds) is the optimal role for export promotion agencies. A liberal trade regime would achieve this, and the agencies could then devote their resources to providing market information and marketing assistance.

Sharma and Morrissey (Chapter 6) investigate the consequences of trade liberalisation on export diversification and growth in Nepal, a landlocked low-income country. There is some evidence for a rise in export intensity, especially for manufactured exports, and a fall in the export share of primary products following trade liberalisation. This provides some support for the notion that trade liberalisation contributes to export diversification and growth. However, the structure of the Nepalese economy is not conducive to exportled growth, primarily because manufactured exports are dominated by two items (carpets and garments) subject to quotas under the generalised system of preferences (GSP) scheme.

Arun and Nixson (Chapter 7) focus on the structural changes that have taken place in Indian policy towards manufacturing development since 1991. Before then the Indian government had maintained 'heavily protectionist' policies. Notably these policies included 'reserved' status for a large number of manufacturing subsectors, whereby only Indian public sector enterprises were permitted to develop capacity. However, despite the protectionist approach, the robustness and size of the Indian economy permitted sustained growth over the forty years from the 1950s to the 1980s. During this period manufacturing and mining increased from 15 to 30 per cent of GDP, and from the mid-1970s to the end of the 1980s manufacturing accounted for 80 to 85 per cent of the stock of direct foreign investment (DFI). However, the manufacturing sector tended towards technological obsolescence, high concentration ratios, and comparative lack of competition. After the 1991 liberalisation, deregulation, privatisation and more favourable policies towards DFI were pursued. DFI approvals increased substantially over the period 1991 to 1998 , 
but over this period only about 30 per cent of the approvals by value were converted into actual investment. This slow conversion of 'approvals' into 'actuals' is a feature of 'liberalisation' which has also been noted in Ghana (Acheampong and Tribe, 1998) - emphasising inter alia the importance of time lags between policy change and response, and the build up of business confidence. Indian experience post-1991 has not demonstrated a clear 'watershed' in industrial development and performance. However, the indications are that increased market orientation and attention to the minutiae of competitiveness will reap dividends in the medium- to long-term. An important issue in this context is that of technological capability, reflecting the findings of Mainga in his study of Zambian manufacturing (Chapter 3).

Livingstone (Chapter 8) addresses the microenterprise sector in Cambodia, from the perspective of policies towards providing credit and generating employment. As has been noted above, manufacturing firms in general cite access to credit as a problem. This is more extreme in the case of microenterprises, which tended to be excluded from the 'formal' credit (banking) sector. Cambodia, like any low-income economy, exhibits a pattern of demand that is biased towards goods that are affordable by the poor. This implies that there is a market for 'informal sector' production, and microenterprise production can stimulate manufacturing development from the bottom up. Furthermore, the size of the domestic market limits the scope for any large scale production (with the possible exception of garment factories, directed towards export). The study shows, at least for Cambodia, that the successful NGO credit schemes have benefited primarily those in rural areas. While this is desirable in itself, it fails to address the problem of enterprise development. Microenterprises, especially in urban areas, are still denied access to credit.

Middleton (Chapter 9) finds no evidence that neo-liberal adjustment policies in Ecuador did anything but harm to petty manufacturers, a segment of the economy that is assumed to be dynamic. It appears to be small-scale manufacturers of subsistence goods that fared worst. In times of economic boom, they lost market share to larger-scale producers of basic consumption goods, whereas during economic decline their potential market shrank. On the other hand, small-scale producers of production goods, such as mechanics and printers, were able to grow by servicing the needs of larger firms. The rate at which firms were disappearing was high and reasonably constant across all activities. The big difference between the different types of activity was the rate at which replacements were taking place; the replacement was much higher for producers of 'production goods' (e.g. mechanics) than of subsistence goods. Overall, the numbers employed in 'informal sector' activities in Quito declined by over 20 per cent between 1975 and 1995; the numbers producing basic consumer goods declined by about half, whereas the numbers producing production goods rose, but only 
by six per cent. The two clear areas of growth were in bakers and beauty salons, where numbers employed almost doubled. However, on the evidence from Quito, most of the growth (and decline) was in numbers of microenterprises rather than in the size of enterprises. These patterns are not due to any active government policy. In fact, the government had no policy; the neo-liberal economic paradigm applied in Ecuador assumed that if markets were liberalised, dynamic entrepreneurs would benefit and grow. Although informal microenterprises were certainly dynamic in a practical sense, they tended not to grow (Teal, 1998 shows the absence of growth dynamics in small firms in Ghana). The evidence suggests that positive government policies are necessary to support a truly dynamic and growing microenterprise sector.

Migdad et al. (Chapter 10) conduct a detailed analysis of the industrial sector in Gaza. They find evidence of great diversity within the small firm sector, with high rates of start-up combined with high rates of closure, and some firms growing whilst others contract. However, within the small firm sector, performance does not appear to be related to size or to age (there is no evidence of learning by doing). Access to finance and scarcity of raw materials do appear to be constraints. The most significant finding is that clothing firms, especially those engaged in subcontracting for Israeli firms, are the most dynamic and perform best on most criteria. Such dependence on Israel for access to markets in low labour cost sectors is not, however, a viable development strategy for Gaza.

\section{CONCLUSIONS}

The explicit intention of economic policy reform is to alter the incentives facing different sectors in the economy so as to encourage the growth of the most efficient sectors. Specifically, the argument for liberalisation is that one is starting from a position of a distorted economy and it is desirable to remove these distortions. For example, a highly protectionist trade regime reduces the incentives to exporting but encourages inefficiency in IS industries. Domestic policies towards agriculture, industry or finance, for example, may exacerbate these distortions. Obviously, when these distortions are removed the previously sheltered or supported sectors will face increased competition. To the extent that they are unable to increase efficiency to respond to this competition, these sectors will decline. The issue in terms of the net impact on manufacturing is the speed and extent of decline in some sectors relative to the expansion in those sectors facing improved incentives.

All of the studies in this volume demonstrate that there remains a role for active government policy during periods of liberalisation. In particular, the 
government can facilitate the ability of firms to respond to the change in relative incentives. This is true whether firms are competing with imports or are exporting. In both cases, government policies towards or assistance in investment, adopting technology or finding new market opportunities can facilitate the speed of adjustment. The basic point is that macroeconomic or trade policy changes alter incentives, but microeconomic policies can affect the ability of firms to respond to these changes.

The principal microeconomic policies we have in mind are those relating to access to finance for investment, access to technology and capabilities more generally, and information about market opportunities. The government can also play a role in reducing the infrastructure and institutional constraints to manufacturing. There is nothing inherently new in these conclusions, but this does not make them any less deserving of emphasis. One of the problems faced in low-income countries is that the ability of the government to implement supporting policies is often limited. Infrastructure projects, for example, are expensive and have a long gestation period. Furthermore, the banking sector is often inefficient and credit-constrained (this is one major reason why foreign investment can play such an important role). The case studies in this volume do not offer solutions to these problems. Rather, they highlight the need for accommodating investment, industry and infrastructure policies in an environment of economic policy reform. It would be wrong to make the 'textbook assumption' that private agents can quickly respond to changes in relative incentives, even if these changes are desirable in themselves.

Nevertheless, the evidence from the case studies is not unduly pessimistic. Even in very poor countries such as Ghana, Uganda and Nepal, the manufacturing sector has responded reasonably well to liberalisation. In a large, albeit poor, country such as India the response is more encouraging. Liberalisation is not a panacea, but nor is it the evil it is sometimes portrayed as. Firms will respond to incentives, but governments should be aware of the types of assistance that are warranted. There is one note of caution: the studies in Ecuador, Cambodia and Gaza all highlight the particular vulnerability of small-scale enterprises. In an era of 'globalisation', this is an area of manufacturing policy that requires further study.

\section{REFERENCES}

Acheampong, I.K. (1996), The Impact of the Economic Recovery Programme (198390) on Industrial Performance in Ghana, unpublished PhD Thesis, University of Bradford.

Acheampong, I.K. and M.A. Tribe (1998), 'The Response of Ghana's Manufacturing Sector to Structural Adjustment', in Cook, P., Kirkpatrick, C. and Nixson, F.I. 
(eds), Privatisation, Entrepreneurship and Economic Reform, Edward Elgar, Cheltenham.

African Development Bank (1998), African Development Report 1998, Oxford University Press, Oxford.

Bennell, P. (1998), 'Fighting for Survival: Manufacturing Industry and Adjustment in Sub-Saharan Africa', Journal of International Development, 10, 621-637.

Chenery, H.B., S. Robinson and M. Syrquin (1986), Industrialization and Growth: A Comparative Study, Oxford University Press for the World Bank, New York.

Chhibber, A. and C. Leechor (1995), 'From Adjustment to Growth in Sub-Saharan Africa: the Lessons of East Asian Experience Applied to Ghana', Journal of African Economies, 4, 83-114.

Greenaway, D. (1998), 'Does Trade Liberalisation Promote Economic Development', Scottish Journal of Political Economy, 45, 491-511.

Greenaway, D., C.W. Morgan and P. Wright (1997), 'Trade Liberalisation and Growth in Developing Countries: Some New Evidence', World Development, 25, 1885-92.

Greenaway, D., C.W. Morgan and P. Wright (1998), 'Trade Reform, Adjustment and Growth: What Does the Evidence Tell Us?', Economic Journal, 108, 1547-61.

Greenaway, D. and O. Morrissey (1993), 'Structural Adjustment and Liberalisation in Developing Countries: What Lessons Have We Learned?', Kyklos, 46, 241-61.

Greenaway, D. and O. Morrissey (1994), 'Trade Liberalisation and Economic Growth in Developing Countries', in Murshed, S.M. and Raffer, K. (eds), Trade Transfers and Development, Edward Elgar, Cheltenham, 210-32.

Grenier, L., A. McKay and O. Morrissey (1999), 'Exporting, Ownership and Confidence in Tanzanian Enterprises', The World Economy, 22, 995-1012.

Grenier, L., A. McKay and O. Morrissey (2000), 'Ownership and Export Performance in Tanzanian Enterprises', in Jalilian, H. Tribe, M. and Weiss, J. (eds), Industrial Development and Policy in Africa, Edward Elgar, Cheltenham, 244-59.

Helleiner, G.K. (ed.) (1994), Trade Policy and Industrialisation in Turbulent Times, Routledge, London.

Jalilian, H., M.A. Tribe and J. Weiss (eds) (2000), Industrial Development and Policy in Africa, Edward Elgar, Cheltenham.

Lall, S. and F. Stewart (1996), 'Trade and Industrial Policies in Africa', in Ndulu, B. and de Walle, N. (eds), Agenda for Africa's Economic Renewal, US-Third World Policy Perspectives No 21, Overseas Development Council, Transaction Publishers, New Brunswick.

Lall, S. and S. Wangwe (1998), 'Industrial Policy and Industrialisation in SubSaharan Africa', Journal of African Economies, 7, Supplement 1, 70-107.

McGillivray, M. and O. Morrissey (eds) (1999), Evaluating Economic Liberalisation, Macmillan, London.

Milner, C. and O. Morrissey (1999), 'Measuring Trade Liberalisation', chapter 3 in McGillivray and Morrissey (1999).

Milner, C., O. Morrissey and N. Rudaheranwa (2000), 'Policy and Non-Policy Barriers to Trade and the Implicit Taxation of Exports in Uganda', Journal of Development Studies, 37(2), 67-90.

Morrissey, O. (1999), 'Trade Policy Reform in Sub-Saharan Africa: Achievements, Effects and Prospects', paper presented at the 4th SCUSA Inter-University Colloquium, University of East Anglia, September.

Mulaga, G. and J. Weiss (1996), 'Trade Reform and Manufacturing Performance in Malawi 1970-1991', World Development, 24, 1266-78. 
Noorbakhsh, F. and A. Paloni (1998), 'Structural Adjustment Programmes and Export Supply Response', Journal of International Development, 10, 555-73.

Onafowora, O. and O. Owoye (1998), 'Can Trade Liberalization Stimulate Economic Growth in Africa', World Development, 26, 497-506.

Papageorgiou, D., M. Michaely and A. Choksi (1991), Liberalizing Foreign Trade, 7 volumes, Basil Blackwell, Oxford.

Rodrik, D. (1992a), 'Conceptual Issues in the Design of Trade Policy for Industrialisation', World Development, 20, 309-20.

Rodrik, D. (1992b), 'The Limits of Trade Policy Reform in Developing Countries', Journal of Economic Perspectives, 6, 87-105.

Rodrik, D. (1999), The New Global Economy and Developing Countries: Making Openness Work, ODC Policy Essay No. 24, Johns Hopkins University Press, Washington, DC.

Rudaheranwa, N. (1999), Transport Costs and Export Trade of Landlocked Countries: Evidence from Uganda, unpublished $\mathrm{PhD}$ Thesis, University of Nottingham.

Sharma, K., S. Jayasuriya and E. Oczkowski (2000), 'Liberalisation and Productivity Growth: The Case of Manufacturing Industries in Nepal', Oxford Development Studies, 28, 205-22.

Söderbom, M. and F. Teal (2000), 'Skills, Investment and Exports from Manufacturing Firms in Africa', Journal of Development Studies, 37(2), 14-43.

Teal, F. (1998), The Ghanaian Manufacturing Sector 1991-1995: Firm Growth, Productivity and Convergence, Working Paper Series - WPS/98-17, Centre for the Study of African Economies, University of Oxford.

Tribe, M. (2000), 'A Review of Recent Manufacturing Sector Development in SubSaharan Africa', in Jalilian et al. (2000), pp. 75-106. 